\title{
ANALISIS KEMAMPUAN PENALARAN MATEMATIS SISWA MELALUI PENDEKATAN PROBLEM POSING DI KELAS X IPA 1 SMA NEGERI 9 MALANG
}

\author{
Siti Zaenab \\ SMP Muhammadiyah 3 Malang \\ Email: namakuzaenab@gmail.com
}

\begin{abstract}
Abstrak
Penelitian ini berawal dari guru masih cenderung menggunakan metode ceramah, siswa kurang diberi latihan tentang kemampuan penalaran matematis dalam membuat dan menyelesaikan sebuah permasalahan. Pendekatan Problem Posing merupakan pendekatan pembelajaran yang menuntut siswa agar mengembangkan kemampuan penalaran matematisnya dalam membuat soal dan menyelesaikan soal. Sehingga pendekatan yang digunakan dalam penelitian ini adalah Pendekatan Problem Posing. Hasil penelitian dari keterlaksanaan pembelajaran matematika melalui pendekatan Problem Posing yang dilakukan oleh guru dan siswa pada dua pertemuan terlaksana dengan baik. Dari hasil analisis siswa I,II,III,dan IV diperoleh rata-rata siswa tidak dapat menyajikan pernyataan matematika dalam bentuk diagram dengan benar.
\end{abstract}

Kata Kunci: Kemampuan Penalaran Matematis, Pendekatan Problem Posing

\begin{abstract}
This research derived from the problem that teacher tends to use lecturing method and there is lack of practice on mathematical reasoning ability for students in making and solving problems. Problem posing is an approach that demands students to develop their mathematical reasoning ability in making and solving problem; therefore, the appropriate approach in this research is Problem Posing learning approach. The findings of the research showed the successfulness of the Problem Posing approach in the mathematics learning process which was conducted in two meetings are considered good. From the analysis of the students I, II, III, and IV, is found that most of the students cannot present mathematical statement in the form of diagram in correct manners.
\end{abstract}

Keywords: Mathematics Reasoning ability, Problem Posing Approach

\section{PENDAHULUAN}

Proses pendidikan dilaksanakan sedemikian rupa agar dapat memahami dan menghayati makna pendidikan tersebut, sehingga dapat bermanfaat untuk membantu dirinya dalam menghadapi perkembangan ilmu dan pengetahuan. Keberhasilan proses pembelajaran merupakan tujuan utama yang diharapkan dalam melaksanakan pembelajaran di sekolah. Upaya untuk mencapai keberhasilan tersebut, pemerintah telah membuat kurikulum yang telah disesuaikan dengan keadaan dan kemampuan setiap jenjang pendidikan. Hal ini sejalan dengan standart kompetensi lulusan kurikulum 2013 pada dimensi keterampilan yaitu memiliki kemampuan berfikir, tindakan yang efektif dan kreatif dalam ranah abstrak dan konkret sesuai dengan yang dipelajari di sekolah dan sumber lain sejenis (Sintawati dan Abdurrahman, 2013).

Sejalan dengan berkembangnya zaman, matematika telah mengalami 
kemunduran, banyak siswa yang menganggap bahwa matematika merupakan pelajaran yang sangat sulit bahkan sebagian siswa mengatakan matematika merupakan pelajaran yang sangat menakutkan (Jannah, 2011). Salah satu munculnya pemikiran tersebut, disebabkan karena kurang menariknya guru dalam mengemas atau menyalurkan pengetahuan kepada siswa tentang matematika. Tate dan Johnson juga berpendapat bahwa salah satu indikator guru yang berkualitas adalah bagaimana baiknya guru memahami proses berpikir dan penalaran siswa tentang matematika dan bagaimana memperluas kemampuan mereka (Kamid, 2009).

Tujuan dari kurikulum 2013 adalah siswa mampu bernalar, sehingga salah satu pendekatan pembelajaran yang efektif untuk menumbuhkan kemampuan penalaran matematis siswa adalah pendekatan Problem Posing. Pendekatan Problem Posing merupakan salah satu alternatif model pembelajaran yang dapat mengembangkan kemampuan berfikir matematis, karena pendekatan Problem Posing merupakan pembelajaran yang menuntut siswa agar mengembangkan kemampuan penalarannya dalam hal membuat soal maupun penyelesaiannya. SMA Negeri 9 Malang merupakan salah satu sekolah di Malang yang telah menggunakan kurikulum 2013. Sekolah ini telah menggunakan dua kurikulum yaitu kurikulum KTSP dan Kurikulum 2013. Disamping itu, SMA Negeri 9 Malang pernah digunakan penelitian pembelajaran menggunakan pendekatan Problem Posing dan memperoleh hasil yang bagus. Sehingga peneliti bermaksud mengadakan penelitian yang berjudul “Analisis
Kemampuan Penalaran Matematis Siswa Melalui Pendekatan Problem Posing di Kelas X SMA Negeri 9 Malang".

\section{Pendekatan Problem Posing}

Pendekatan Problem Posing adalah suatu pendekatan dalam proses pembelajaran yang bertujuan agar siswa dapat mengajukan atau membuat soal berdasarkan informasi atau data yang telah diberikan oleh guru serta menyelesaikan soal yang telah dibuat, sehingga siswa dapat mengembangkan kemampuan berpikir matematis atau menggunakan pola pikir matematis. Hal ini sama halnya dengan pengertian pendekatan Problem Posing yang dikemukakan oleh Muzdalipah (2010) bahwa pendekatan Problem Posing merupakan suatu pendekatan yang bertujuan untuk menggali ide-ide, argumen-argumen dan cara-cara yang berbeda dari mahasiswa melalui pengembangan masalah atau soal matematika memformulasikan kembali masalah tersebut berdasarkan situasi masalah yang berkaitan.

Kriteria pembuatan masalah atau soal Problem Posing harus memenuhi syarat: (1) Pembuatan soal harus berhubungan dengan apa yang dimunculkan dari permasalahan yang diberikan; (2) Pembuatan soal mengandung masalah yang dapat dipecahkan; dan (3) Pembuatan soal dihasilkan dari permasalahan yang ada dalam petunjuk (Thobroni dan Mustofa, 2013).

Langkah-langkah pembelajaran dengan pendekatan Problem Posing yang digunakan dalam penelitian ini adalah sebagai berikut: 


\begin{tabular}{|c|c|}
\hline Kegiatan Guru & Kegiatan Siswa \\
\hline $\begin{array}{l}\text { 1. Menyampaikan } \\
\text { pembelajaran yang sesuai dengan } \\
\text { kompetensi dasar dan pendekatan } \\
\text { yang akan digunakan dalam } \\
\text { pembelajaran }\end{array}$ & $\begin{array}{lll}\text { Berusaha } & \text { memahami } & \text { tujuan, } \\
\text { kompetensi, dan pendekatan } & \text { dalam } \\
\text { pembelajaran }\end{array}$ \\
\hline 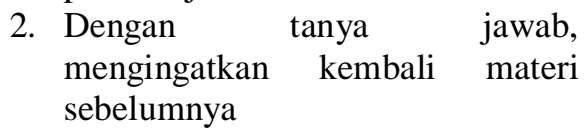 & $\begin{array}{l}\text { Berusaha menjawab dan mengingat } \\
\text { kembali materi sebelumnya }\end{array}$ \\
\hline $\begin{array}{l}\text { 3. Menyajikan materi pembelajaran } \\
\text { dengan strategi yang sesuai dan } \\
\text { selalu berusaha melibatkan siswa } \\
\text { dalam kegiatan }\end{array}$ & $\begin{array}{l}\text { Berusaha berpartisipasi aktif dalam } \\
\text { kegiatan pembelajaran }\end{array}$ \\
\hline $\begin{array}{l}\text { 4. Dengan tanya jawab membahas } \\
\text { kegiatan dengan menggunakan } \\
\text { pendekatan Problem Posing } \\
\text { dengan memberikan contoh atau } \\
\text { cara membuat soal. }\end{array}$ & $\begin{array}{l}\text { Berusaha memahami contoh dan cara } \\
\text { membuat soal yang telah dijelaskan } \\
\text { oleh guru }\end{array}$ \\
\hline $\begin{array}{l}\text { 5. Memberi kesempatan kepada } \\
\text { siswa untuk menanyakan hal-hal } \\
\text { yang dirasa belum jelas }\end{array}$ & $\begin{array}{l}\text { Mencoba menanyakan kepada guru } \\
\text { apabila ada hal yang kurang jelas }\end{array}$ \\
\hline $\begin{array}{l}\text { 6. Memberikan kesempatan kepada } \\
\text { siswa untuk membuat soal dan } \\
\text { penyelesaiannya sesuai dengan } \\
\text { situasi yang diberikan. Kegiatan } \\
\text { ini dilakukan secara berkelompok }\end{array}$ & $\begin{array}{l}\text { Membuat soal dan } \\
\text { berdasarkan situasi } \\
\text { secara kelompok }\end{array}$ \\
\hline $\begin{array}{l}\text { 7. Mengawasi siswa dalam proses } \\
\text { membuat dan mengerjakan soal }\end{array}$ & $\begin{array}{l}\text { Membuat dan mengerjakan soal dengan } \\
\text { teliti dan sungguh-sungguh }\end{array}$ \\
\hline $\begin{array}{l}\text { 8. Mengumpulkan soal dan jawaban } \\
\text { yang telah dikerjakan dan menukar } \\
\text { soal pada kelompok lain }\end{array}$ & $\begin{array}{l}\text { Mengumpulkan soal dan jawaban yang } \\
\text { telah dibuat dan bersiap-siap untuk } \\
\text { mengerjakan soal dari kelompok lain }\end{array}$ \\
\hline $\begin{array}{l}\text { 9. Meminta salah satu kelompok } \\
\text { untuk mempresentasikan di depan } \\
\text { kelas }\end{array}$ & $\begin{array}{l}\text { Mempresentasikan hasil kerja kelompok } \\
\text { di depan kelas }\end{array}$ \\
\hline $\begin{array}{l}\text { 10. Mengarahkan siswa untuk } \\
\text { membuat kesimpulan dari materi } \\
\text { yang sudah dipelajari }\end{array}$ & $\begin{array}{l}\text { Berusaha untuk dapat menyimpulkan } \\
\text { materi yang sudah dipelajari }\end{array}$ \\
\hline
\end{tabular}

\section{Kemampuan Penalaran Matematis}

Berdasarkan penjelasan tentang kamampuan siswa dan penalaran matematis yang telah dipaparkan diatas dapat disimpulkan bahwa kemampuan penalaran matematis adalah kesanggupan, kecakapan, keahlian, atau kepandaian siswa dalam proses berpikir matematika untuk menarik kesimpulan atau membuat pernyataan. Terdapat banyak cara untuk mengembangkan kemampuan penalaran matematis siswa diantaranya adalah guru memacu siswa agar mampu berpikir logis

dengan memberikan soal-soal penerapan sesuai dengan kehidupan sehari-hari yang kemudian diubah dalam bentuk matematika (Sa'adah, 2010).

Materi matematika dan penalaran matematika merupakan dua hal yang tidak dapat dipisahkan, yaitu materi matematika dipahami melalui penalaran, dan penalaran dipahami dan dilatih melalui belajar materi matematika, sehingga kemampuan penalaran matematis sangat penting dan dibutuhkan dalam mempelajari matematika. 
Penggunaan pendekatan Problem Posing dalam pembelajaran matematika dapat menjadi salah satu sarana untuk mengembangkan kemampuan penalaran matematis siswa. Pendekatan ini dapat digunakan karena pembelajaran dengan pendekatan ini dapat mendorong dan melatih siswa dalam merumuskan soal matematik dan kemudian merumuskan penyelesaian dari soal matematik tersebut.

\section{Indikator Kemampuan Penalaran Matematis}

Tercapai tidaknya suatu tujuan, maka diperlukan suatu alat ukur. Dalam penelitian ini, alat ukur yang digunakan adalah indikator kemampuan penalaran matematis melalui pendekatan Problem Posing. Dengan adanya indikator tersebut maka kemampuan penalaran matematis siswa melalui pendekatan dapat diketahui. Adapun indikator kemampuan penalaran matematis siswa melalui pendekatan Problem Posing adalah sebagai berikut:

1) Pembuatan soal dihasilkan dari permasalahan yang ada

2) Pembuatan soal mengandung masalah yang dapat dipecahkan

3) Kemampuan menyajikan pernyataan matematika dalam bentuk diagram

4) Kemampuan mengajukan dugaan diketahui dan ditanya dari soal

5) Kemampuan menentukan pola

6) Kemampuan melakukan manipulasi matematika

7) Kemampuan menarik kesimpulan

\section{METODE}

Jenis dan pendekatan yang digunakan dalam penelitian ini adalah deskriptif kualitatif, karena penelitian ini digunakan untuk meneliti kondisi obyek yang alamiah, dimana peneliti adalah sebagai instrumen kunci dan lebih menekan proses dari pada hasil (Sugiyono, 2011). Sehingga dengan adanya penelitian ini, dapat mengetahui secara detail informasi mengenai subjek yang diteliti. Subjek penelitian adalah guru matematika dan siswa kelas X IPA 1 SMAN 9 Malang.

Teknik analisis data ini digunakan untuk menganalisis data dari keterlaksanaan pembelajaran dengan menggunakan pendekatan Problem Posing dan untuk melihat kemampuan penalaran matematis siswa melalui pendekatan Problem Posing.

\section{Analisis Keterlaksanaan Pembelajaran Matematika Melalui Pendekatan Problem Posing}

Panduan analisis hasil keterlaksanaan proses pembelajaran matematika dengan menggunakan pendekatan Problem Posing dilakukan oleh dua observer yaitu guru mata pelajaran matematika dan teman sejawat. Adapun panduan analisis keterlaksanaan pembelajaran melalui pendekatan Problem Posing dipaparkan dalam tabel berikut ini:

Tabel Persentase dan Taraf Keterlaksanaan Pembelajaran Matematika Melalui Pendekatan Problem Posing

\begin{tabular}{cc}
\hline Persentase Keterlaksanaan & Taraf Keterlaksanaan \\
\hline $81 \%-100 \%$ & Sangat baik \\
$61 \%-80 \%$ & Baik \\
$41 \%-60 \%$ & Cukup \\
$21 \%-40 \%$ & Kurang \\
$0 \%-20 \%$ & Sangat kurang \\
\hline
\end{tabular}

(Riduwan dan Akdon, 2006) 
Perhitungan persentase keterlaksanaan proses pembelajaran menggunakan pendekatan Problem Posing:

persentase keterlaksanaan

$=$ Jumlah skor tercapai $\times 100 \%$ Jumlah skor maksima

Analisis Kemampuan Penalaran Matematis Siswa melalui Pendekatan Problem Posing

Analisis tes kemampuan penalaran Problem Posing hanya untuk empat orang siswa yang mempunyai predikat sangat baik, baik, cukup baik, dan kurang baik. Predikat tersebut diambil dari hasil nilai ujian tengah semester (UTS). Alasan peneliti menganalisis sebagian dari siswa kelas X IPA 1 adalah untuk mendapatkan gambaran kemampuan penalaran matematis siswa di kelas X IPA 1 sesuai dengan predikatnya. Selanjutnya akan dianalisis sesuai dengan indiaktor ketercapaian kemampuan penalaran matematis siswa melalui pendekatan Problem Posing.

Berdasarkan aspek penilaian tes kemampuan penalaran Problem Posing, peneliti menggunakan tujuh indikator ketercapaian kemampuan penalaran matematis siswa melalui pendekatan Problem Posing yaitu (1) Pembuatan soal dihasilkan dari permasalahan yang ada. Pada aspek ini, diharapkan siswa mampu membuat soal dengan benar sesuai dengan informasi yang telah diberikan oleh guru; (2) Pembuatan soal mengandung masalah yang dapat dipecahkan. Pada aspek ini, diharapkan siswa mampu membuat soal dengan benar dan mengandung masalah yang dapat dipecahkan; (3) Kemampuan menyajikan pernyataan matematika dalam bentuk diagram. Pada aspek ini, diharapkan siswa menyajikan pernyataan matematika dalam bentuk diagram; (4) kemampuan mengajukan dugaan diketahui dan ditanya sebelum mengerjakan soal. Pada aspek ini, diharapkan siswa dapat menduga apa yang diketahui dan ditanya dengan benar sebelum mengerjakan soal; (5) kemampuan menentukan pola. Pada aspek ini, diharapkan siswa menuliskan rumus dalam menyelesaikan soal; (6) kemampuan melakukan manipulasi matematika. Pada aspek ini, diharapkan siswa menuliskan proses dalam menyelesaikan soal yang telah dibuat; dan (7) kemampuan menarik kesimpulan. Pada aspek ini, diharapkan siswa menuliskan kesimpulan dari penyelesaian soal yang telah dibuat.

\section{HASIL DAN PEMBAHASAN Keterlaksanaan Pembelajaran Matematika Melalui Pendekatan Problem Posing}

Observasi keterlaksanaan pembelajaran matematika menggunakan pendekatan Problem Posing dilakukan dari mulai peneliti mengawali pembelajaran di kelas sampai peneliti mengakhiri pembelajaran di kelas dan dilaksanakan sebanyak dua kali pertemuan. Observer bertugas mengamati kegiatan yang dilakukan oleh guru dan siswa selama kegiatan belajar mengajar berlangsung. Tujuan dari observasi tersebut adalah untuk mengetahui keterlaksanaan pembelajaran matematika menggunakan pendekatan Problem Posing termasuk kategori sangat baik, baik, cukup, kurang, dan sangat kurang.

Tabel Hasil Observasi Kegiatan Guru dan Siswa

\begin{tabular}{ccc}
\hline Pertemuan & Kegiatan Guru (\%) & Kegiatan Siswa (\%) \\
\hline Pertama & 61.67 & 68.34 \\
Kedua & 66.67 & 68.34 \\
\hline
\end{tabular}


Tabel diatas merupakan hasil observasi kegiatan guru dan siswa pada pembelajaran matematika dikelas X IPA 1 menggunakan pendekatan Problem Posing yang di observasi oleh dua observer. Keterlaksanaan pembelajaran dengan menggunakan pendekatan Problem Posing pada pertemuan pertama yang dilakukan oleh guru mencapai persentase 61,67\% dengan taraf keterlaksanaan baik dan kegiatan yang dilakukan oleh guru pada pertemuan kedua mencapai persentase $66,67 \%$ dengan taraf keterlaksanaan baik juga.

Keterlaksanaan pembelajaran dengan menggunakan pendekatan Problem Posing pada pertemuan pertama yang dilakukan oleh siswa mencapai persentase 68,34\% dengan taraf keberhasilan baik dan kegiatan yang dilakukan siswa pada pertemuan kedua mencapai persentase 68,34\% dengan taraf keterlaksanaan baik. Secara keseluruhan dari penjabaran diatas dapat disimpulkan bahwa keterlaksanaan pembelajaran menggunakan pendekatan Problem Posing yang dilakukan oleh guru dan siswa kelas X IPA 1 SMA Negeri 9 Malang terlaksana dengan baik. Keterlaksanaan pembelajaran tidak dapat terlaksana dengan sangat baik dikarenakan terdapat beberapa kendala yaitu beberapa siswa tidak sungguh-sungguh dalam kegiatan belajar dan pembelajaran di kelas dan peneliti kurang dapat menguasai ruang kelas.

Setelah pembelajaran terlaksana dengan baik, kegiatan dapat dilanjutkan dengan memberikan tes kemampuan penalaran Problem Posing pada siswa yang bertujuan untuk mengetahui kemampuan penalaran matematis siswa kelas X IPA 1 setelah mengikuti pembelajaran matematika dengan menggunakan pendekatan Problem Posing.

\section{Kemampuan Penalaran Matematis Siswa Melalui Pendekatan Problem Posing}

Data kemampuan penalaran siswa diperoleh melalui analisis terhadap hasil tes yang dilakukan siswa pada pertemuan kedua. Tes yang diberikan kepada siswa berupa tes membuat soal dan penyelesaiannya dari informasi yang telah diberikan oleh peneliti. Adapun indikator tes kemampuan penalaran Problem Posing terdapat pada penjelasan diatas.

Paparan hasil analisis kemampuan penalaran Problem Posing siswa dalam mengerjakan tes oleh 4 siswa, yaitu siswa I dengan predikat sangat baik di kelas, siswa II dengan predikat baik di kelas, siswa III dengan predikat cukup baik di kelas, dan siswa IV dengan predikat kurang baik di kelas adalah sebagai berikut:

Tabel Hasil Analisis Kemampuan Penalaran Problem Posing

\begin{tabular}{|c|c|c|c|c|c|c|}
\hline Indikator & $\begin{array}{l}\text { Siswa } \\
\mathrm{I}(\%)\end{array}$ & $\begin{array}{l}\text { Siswa } \\
\mathrm{II}(\%)\end{array}$ & $\begin{array}{l}\text { Siswa } \\
\text { III(\%) }\end{array}$ & $\begin{array}{l}\text { Siswa } \\
\text { IV(\%) }\end{array}$ & $\begin{array}{c}\text { Rata- } \\
\text { Rata(\%) }\end{array}$ & Kriteria \\
\hline $\begin{array}{l}\text { 1. Pembuatan soal } \\
\text { dihasilkan dari } \\
\text { permasalahan yang } \\
\text { ada }\end{array}$ & 66,67 & 83,33 & 66,67 & 66,67 & 70,84 & Baik \\
\hline $\begin{array}{l}\text { 2. Pembuatan soal } \\
\text { mengandung } \\
\text { masa lah yang dapat } \\
\text { dipecahkan }\end{array}$ & 66,67 & 83,33 & 66,67 & 66,67 & 70,84 & Baik \\
\hline
\end{tabular}




\begin{tabular}{|c|c|c|c|c|c|c|}
\hline Indikator & $\begin{array}{c}\text { Siswa } \\
\mathrm{I}(\%)\end{array}$ & $\begin{array}{l}\text { Siswa } \\
\text { II(\%) }\end{array}$ & $\begin{array}{l}\text { Siswa } \\
\text { III(\%) } \\
\end{array}$ & $\begin{array}{l}\text { Siswa } \\
\text { IV(\%) }\end{array}$ & $\begin{array}{c}\text { Rata- } \\
\text { Rata(\%) }\end{array}$ & Kriteria \\
\hline $\begin{array}{l}\text { 3. Menyajikan } \\
\text { pernyataan } \\
\text { matematika dalam } \\
\text { bentuk diagram }\end{array}$ & 33,33 & 33,33 & 33,33 & 0 & 25 & Kurang \\
\hline $\begin{array}{l}\text { 4. Mengajukan dugaan } \\
\text { diketahui dan } \\
\text { ditanya sebelum } \\
\text { mengerjakan soal }\end{array}$ & 83,33 & 83,33 & 0 & 83,33 & 62,5 & Baik \\
\hline 5. Menentukan pola & 100 & 100 & 0 & 100 & 75 & Baik \\
\hline $\begin{array}{l}\text { 6. Melakukan } \\
\text { manipulasi } \\
\text { matematika }\end{array}$ & 100 & 77,78 & 83,33 & 66,67 & 81,95 & $\begin{array}{l}\text { Sangat } \\
\text { Baik }\end{array}$ \\
\hline 7. Menarik kesimpulan & 0 & 33,33 & 66,67 & 66,67 & 41,67 & Cukup \\
\hline Rata-rata & 64,29 & 70,63 & 45,24 & 64,29 & 61,11 & Baik \\
\hline
\end{tabular}

Hasil analisis yang dikerkajan siswa I, II, III, dan IV dari tujuh indikator kemampuan penalaran Problem Posing dapat ditarik kesimpulan bahwa siswa sangat baik dalam mencapai indikator yang ke enam. Artinya dalam hal ini rata-rata siswa dapat malakukan manipulasi matematika dengan sangat baik. Disamping itu, rata-rata siswa telah mencapai indikator kemampuan penalaran Problem Posing yang kesatu, kedua, keempat, dan kelima dengan baik walaupun masih terdapat sedikit kesalahan dalam membuat soal sesuai dengan informasi yang telah diberikan, dalam mengajukan dugaan diketahui dan ditanya sebelum mengerjakan soal dan menarik kesimpulan. Hasil ini sesuai dengan Wulandari (2011) dan Sintawati dan Abdurrahman (2013).

\section{SIMPULAN}

Keterlaksanaan pembelajaran matematika dengan menggunakan pendekatan Problem Posing dalam penelitian ini dapat dilihat dari persentase keterlaksanaan pembelajaran matematika yang dilakukan guru dan siswa pada setiap pertemuan. Keterlaksanaan pembelajaran matematika dengan menggunakan pendekatan Problem Posing pada pertemuan pertama dan kedua yang dilakukan siswa dan guru mencapai taraf keterlaksanaan baik. Keterlaksanaan pembelajaran tidak dapat terlaksana dengan sangat baik dikarenakan terdapat beberapa kendala yaitu beberapa siswa tidak sungguh-sungguh dalam kegiatan belajar dan pembelajaran di kelas dan guru kurang dapat menguasai kondisi kelas.

Kemampuan penalaran matematis melalui pendekatan Problem Posing pada siswa I secara keseluruhan memperoleh kriteria baik. Hasil tes yang dikerjakan oleh siswa II secara keseluruhan memperoleh kriteria baik. Hasil tes yang dikerjakan oleh siswa III secara keseluruhan memperoleh kriteria cukup. Hasil tes yang dikerjakan oleh siswa IV memperoleh kriteria baik. Kemampuan penalaran Problem Posing siswa I,II,III, dan IV belum mencapai kriteria sangat baik dikarenakan rata-rata siswa tidak dapat menyajikan pernyataan matematika dalam bentuk diagram dengan benar. Oleh 
karenannya diharapkan guru dapat menjelaskan cara menggambar diagram garis dengan benar.

\section{DAFTAR PUSTAKA}

Jannah, R. 2011. Membuat Anak Cinta Matematika dan Eksak lainnya. Yogyakarta: DIVA Press.

Kamid. 2009. Identifikasi Proses Berpikir Anak Autis dalam Menyelesaikan Soal Matematika. Prosiding Seminar Nasional Matematika. Fakultas MIPA Universitas Jember: 907-920.

Muzdalipah, Ipah. 2010. Peningkatan Kemampuan Pemecahan Masalah Matematika Melalui Pendekatan problem Posing. Prosiding Seminar Nasional Matematika dan Pendidikan Matematika: FKIP UMM, 258-266.

Riduwan dan Akdon. 2006. Rumus dan Data dalam Aplikasi Statistika. Bandung: Alfabeta.

Sa'adah, W. 2010. Peningkatan Kemampuan Penalaran Matematis Siswa Kelas VIII SMP Negeri 3 Banguntapan dalam Pembelajaran Matematika Melalui Pendekatan Pendidikan Matematika Realistik Indonesia(PMRI). Skripsi. Program Sudi Pendidikan Matematika UNY. Yogyakarta.

Sintawati, M dan Abdurrahman, G. 2013. Menumbuhkan Kemampuan Berfikir Kreatif dan Minat Belajar Matematika Melalui Pendekatan Problem Posing. Prosiding Seminar Nasional Matematika dan Pendidikan Matematika: FMIPA UNY, 437442.

Sugiyono. 2010. Metode Penelitian Kualitatif dan R\&D. Bandung: Alfabeta
Thobroni, M dan Mustofa, A. 2013. Belajar dan Pembelajaran Mengembangkan Wacana dan Praktik Pembelajaran dalam Pembangunan Nasional. Jogjakarta: Ar-Ruzz Media

Wulandari, E. 2011. Meningkatkan Kemampuan Penalaran Matematis Melalui Pendekatan Problem Posing di Kelas VIII A SMP Negeri 2 Yogjakarta. Skripsi. Program Studi Pendidikan Matematika Universitas Negeri Yogyakarta. 